\title{
細胞周期制御異常による発癌および悪性化機構
}

\author{
佐谷 秀行 \\ 熊本大学大学院医学薬学研究部 腫瘍医学分野
}

\begin{abstract}
要旨 増殖能を持つ細胞は細胞周期の過程において遺伝子や染色体に異常が生じると, 一時 的にその進行を停止し，異常を修正する能力があり，組織中に異常細胞が出現することを防 いでいると考えられている。この機構をチェックポイントと呼ぶが，そのチェックポイント 機構そのものに異常が生じると遺伝子や染色体の損傷が蓄積し，細胞の悪性化の原因になる と考えられている。しかし，抗癌剤や放射線による治療は，癌細胞がこのようなチェックポ イントに障害があることを逆に利用したものであることが最近の解析によって分かってきた。 治療によって DNA や染色体に損傷が加わると正常細胞では細胞周期は停止するが，癌細胞で はチェックポイント障害があるため損傷を持ったまま進行し，細胞死が誘導される。しかし， 重度のゲノム变化を持つ腫瘍ではこの細胞死機構すら破綻し, 治療に抵抗性を示すと考えら れる。
\end{abstract}

\section{Implication of cell cycle dysregulation in development and malignant progression of tumors}

Hideyuki SAYA

Department of Tumor Genetics and Biology, Kumamoto University

Cell cycle checkpoints are a regulatory mechanism that prevents transition of cells into subsequent phases until all processes in the previous phase are completed, ensuring genomic integrity. Arrest in G1 is considered to prevent aberrant replication of damaged DNA and arrest in G2 allows cells to avoid segregation of defective chromosomes. Therefore, defective cell cycle checkpoints lead to gene mutations and chromosome damage which contribute to tumorigenesis. However, recent observations indicate that loss of checkpoint function in cancer cells is associated with their sensitivity to antineoplastic treatments such as chemotherapy and radiation. By treatment with those genotoxic agents, cancer cells having impairment of checkpoint functions initially arrest in the G2 phase of the cell cycle but are unable to maintain cell-cycle arrest. Those cells eventually die as they enter mitosis. This process is referred to as 'mitotic catastrophe'. In this review, we propose the critical relationship between checkpoint functions and sensitivity of cancer cells to anti-tumor therapies. [Skin Cancer (Japan) $2004 ; 19: 281-286]$

Key words : Checkpoints, Genomic instability, Mitosis, Mitotic catastrophe 


\section{1.はじめに}

高等生物の身体は，ほとんどが複製や分裂を 停止した細胞によって構成されており，わずか $1 \%$ 程度の細胞が増殖期にあると考えられてい る。しかし，組織構築は，それらわずか $1 \%$ に 含まれる，それぞれの組織固有の幹細胞および その分裂から生じた前駆細胞の複製と分裂が正 確に行われることによって維持されており，そ のステップは多くの分子の連携によって厳密に 制御されている。これら増殖能を持つ細胞の遺 伝子や染色体に傷が生じた場合，細胞は一時的 に細胞周期を停止しその修復を行う。そして, 損傷が修復された場合は細胞周期を再開する が，修復不可能な場合は細胞死を誘導すること により，損傷細胞を組織から除去する作業が行 われる。このステップをチェックポイントと呼 び，個体が正常な組織構築を維持するための重 要な機構として機能している。しかし，チェッ クポイントを制御する分子自身に異常が生じる ことにより, 多発性の遺伝子変異や染色体の不 均等分配など，つまり「ゲノムの不安定化」が 発生し, 細胞の腫瘍化ならびに悪性化が誘発さ れると考えられている。従って, 癌細胞は悪性 度が高くなるほど重度のチェックポイント障害 を持つと考えられている。特に, 分裂期にお けるチェックポイント異常は直接染色体の数や 構造に異常を引き起こすため，悪性化に果たす 役割が大きい。

現在行われている多くの抗癌剂や放射線によ る抗癌治療は, 癌細胞がチェックポイントに障 害を持つという性質を期せずして利用したもの であることが最近の解析によって分かってき た。つまり，薬剤や放射線によってDNA や染 色体に損傷が加わると，正常の細胞ではチェッ クポイントが活性化して細胞周期は停止する が，癌細胞においてはチェックポイント障害が あるため傷を持ったまま次の phaseへと進むこ とになる。特に G2 期のチェックポイント障害
のある腫瘍細胞では損傷を受けた細胞は修復さ れることなく分裂期へ侵入し，そこで細胞死が 誘導されることが抗腫瘍治療の重要なメカニズ ムとなっている。本稿では, 癌細胞における細 胞周期チェックポイントの異常を述べるととも に，その細胞周期異常そのものをターゲットと した治療とその問題点について概説する。

\section{2. 細胞周期進行のエンジン・アクセル・ ブレーキ}

細胞周期回転の原動力となるのは，サイクリ ンと呼ばれるタンパクとそのサイクリンによっ て活性化されるサイクリン依存性キナーゼ （cdk：cyclin-dependent kinase）の複合体であ る。この複合体は多くのタンパク質をリン酸化 することにより細胞内のシグナルを変化させ， 細胞周期を進行させると考えられている。まず $\mathrm{G} 1$ 期から $\mathrm{S}$ 期への移行の引き金を引くのはサ イクリン $\mathrm{D} / \mathrm{cdk} 4$ （あるいは cdk6）の複合体で あり，その発火によってサイクリン $\mathrm{E} / \mathrm{cdk} 2$ 複 合体の活性化が起こり, 細胞は本格的に $\mathrm{S}$ 期に 突入することになる。その後サイクリン $\mathrm{A} / \mathrm{cdk} 2$ の活性化により細胞は $\mathrm{S}$ 期から G2 期へ 移行し, サイクリン $\mathrm{B} / \mathrm{cdc} 2$ (cdk1 とも呼ぶ) の活性化によって細胞は $\mathrm{M}$ 期へ進むことがで きる。 $\mathrm{M}$ 期の後半からサイクリン $\mathrm{B} / \mathrm{cdc} 2$ の活 性は消失しはじめ，G1期に再び戻る時にはす ベてのサイクリン/cdkの活性は消失する。つ まり，それぞれのサイクリン/cdk 複合体の時 期特異的活性化により phaseが進行するのであ り, この複合体は細胞周期進行のエンジンと考 えることができる。サイクリン/cdk複合体の 機能を亢進させるシグナルは細胞周期を回転さ せるアクセルとなり，逆にその機能を抑制する シグナルはブレーキとなる。遺伝子や染色体に 損傷が生じると，これらブレーキに相当するシ グナルが活性化され, 細胞周期は一時的に停止 する。これがチェックポイントの仕組みである。 遺伝子に生じた変化は $\mathrm{G} 1$ 期から $\mathrm{S}$ 期に移行 
する時期（G1チェックポイントと呼ぶ）およ び $\mathrm{G} 2$ 期から $\mathrm{M}$ 期に移行する時期（G2チェック ポイント）においてチェックを受け，染色体に 生じた異常は $\mathrm{M}$ 期（Mチェックポイント）で 検閲を受けることが知られている（図 1)。ま た，S期ではDNA合成が終了するまでは決し て分裂期に入らないように制御されている（S チェックポイント)。腫瘍形成において重要な 意味を持つ $\mathrm{G} 1, \mathrm{G} 2$ および $\mathrm{M}$ チェックポイント の分子機構について以下に解説する。

\section{G1，G2チェックポイントの分子制御}

上述したようにサイクリン D/cdk4（あるい は cdk6）の活性化が $\mathrm{G} 1$ 期から S 期への移行の 引き金を引くシグナルとなる。サイクリン $\mathrm{D} / \mathrm{cdk} 4$ （あるいは cdk6）複合体は，增殖因子 刺激やras, c-mycなど癌遺伝子産物によって 活性化を受け G1/S 移行に必要な標的タンパク 質のリン酸化を行う。標的タンパク質として代 表的なのは，遺伝性網膜芽細胞腫の原因遺伝子 である $\mathrm{Rb}$ 遺伝子にコードされる $\mathrm{Rb}$ タンパク質 である。G1期では E $2 F$ と呼ばれる転写調節因 子と DP-1蛋白（E2F の転写活性を高める因子
といわれている）の複合体は非リン酸化型の $\mathrm{Rb}$ タンパク質と結合していて, E2Fの転写活 性は抑制されている。しかし，増殖シグナルに よってサイクリン D/cdk4（あるいは cdk6）が 活性化されると, $\mathrm{Rb}$ タンパク質はリン酸化を 受けE2F-DP-1 複合体と解離し, E2F は標的遺 伝子，すなわち $\mathrm{S}$ 期への進行に必要な遺伝子群 の転写を立進させる。つまり, サイクリン $\mathrm{D} / \mathrm{cdk} 4$ （あるいはcdk6）による Rbタンパク質 のリン酸化は G1 から $\mathrm{S}$ 期へ細胞周期を進める ために必須のシグナルであると考えられてい る。このシグナルが異常に立進していること (つまりアクセルの過剩反応）によってチェッ クポイントが破綻している例が実際の悪性腫瘍 に多く観察されている。多くの腫瘍で見られる Ras タンパク質の変異, c-myc 遺伝子の変異や 発現克進などは当然サイクリン D/cdk4 複合体 の定常的活性化を引き起こすこととなる。また 食道癌ではサイクリン D 遺伝子の増幅, 脳腫瘍 などでは cdk4 遺伝子の増幅が報告されている。

サイクリン D/cdk4（あるいは cdk6）の活性 は p16, p27そして p21 と呼ばれるタンパク質 によって阻害され（これらは内因性 cdk inhibitors と総称される)，これらがG1期におけ

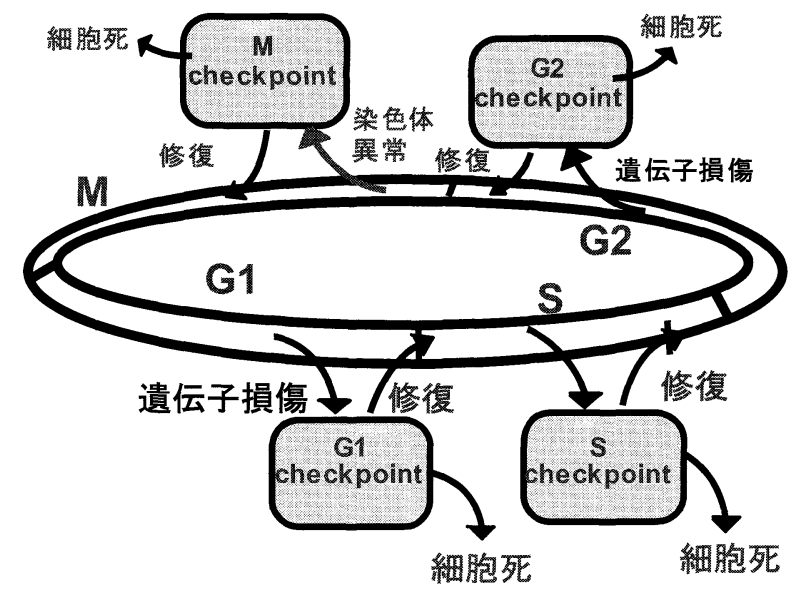

図 1 . 細胞周期チェックポイント

細胞周期において, 遺伝子や染色体の損傷をモニターするチェックポイ ントというシステムが存在する。これらの損傷を受けた細胞は一時的に 細胞周期を停止し，その損傷の修復を試みる. 修復できない場合は細胞 死が誘導され，損傷した細胞は組織から取り除かれることになる 
る細胞周期のブレーキとなる。遺伝子に損傷が 加わると, ATMキナーゼ (ataxia telangiectasiaの責任遺伝子産物）の活性化が起こり, 癌 抑制遺伝子産物 p53のアミノ末端部にリン酸基 を導入する ${ }^{1)}$ 。p 53 タンパク質は mRNAより翻 訳されると MDM2 と呼ばれるタンパク質によっ てユビキチン化を受け，続いてプロテアソーム によって分解を受けるため, 通常の増殖細胞内 での発現量は極めて低い。しかし，ATMによっ てリン酸化されたp53タンパク質はMDM2 と 結合できないため核内に急速に貯留する。貯留 したp53タンパク質は核内で転写因子として働 き, p21の発現を誘導し, それによってサイク リン D/cdk4（あるいはcdk6）が阻害されるた めに, 細胞周期は G1で停止することになる。 これが, 遺伝子損傷によるG1チェックポイン トの活性化機構である。

多くの悪性腫瘍細胞の遺伝子解析により, $\mathrm{p} 53$ 遺伝子の変異欠失, EGF受容体の増幅や変 異, p16遺伝子の不活化, MDM2 遺伝子の増幅 などアクセルとブレーキの異常が大半の腫瘍に 認められることが明らかになった。つまり，悪 性細胞ではその程度に差はあるにしても, ほと んどすべてにおいて G1チェックポイントの異 常が存在すると考えることができる。

$\mathrm{G} 2$ 期から $\mathrm{M}$ 期への進行はサイクリン $\mathrm{B} / \mathrm{cdc} 2$ $(\mathrm{cdk} 1)$ の活性化によって行われ，遺伝子損傷
シグナルはその活性を阻害し, 細胞周期を $\mathrm{M}$ 期侵入の直前で停止させる。 $\mathrm{S}$ 期から G2 期に かけての遺伝子損傷はATM, Chk1, Chk2な ど様々なキナーゼを活性化し，その作用によっ て結果的に cdc2（cdk1）キナーゼ活性を抑制 することが分かっている。興味深いことに，近 年 $\mathrm{p} 53$ は 21 の転写を介して部分的にサイクリ ン B/cdc2 (cdk1) を阻害することが分かり ${ }^{2)}$, $\mathrm{p} 53$ は G1のみならず $\mathrm{G} 2$ チェックポイントにも 重要な役割を果たしていることが明らかになっ た。

\section{Mチェックポイント制御と腫瘍}

細胞分裂期における染色体の分配過程は, 多 くの分子が連携することによって厳重に監視さ れている。すべての姉妹染色体の隣り合った一 対の動原体に両紡錘極から伸張した紡錘系がそ れぞれ付着して，同じ張力で染色体を両極に牽 引する準備ができるまで，染色体の分離は始ま らないように制御されている。従って染色体の 分離は, 染色体や紡錘系に異常があってその アタッチメントに不均衡が生じると，停止する 仕組みになっている（図 2)。これを Mチェッ クポイント (mitotic checkpoint) と呼び, そ の過程が破綻することによって染色体の不均等 分配，あるいは細胞質の分裂障害による多核細

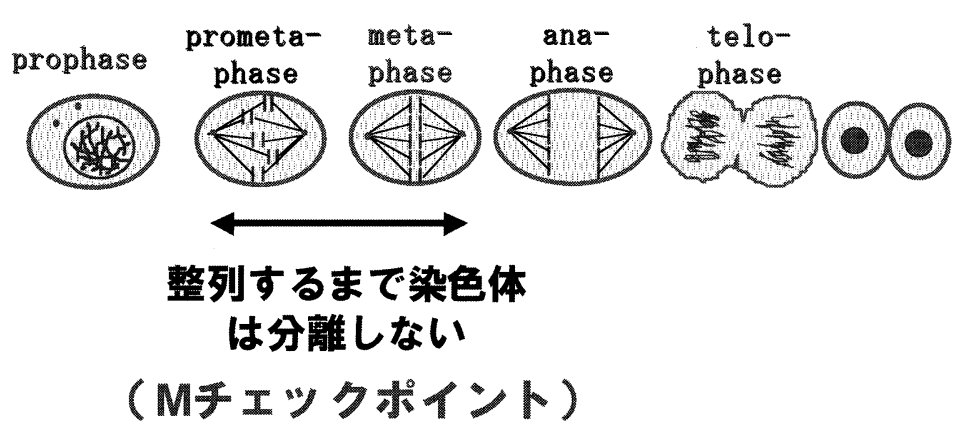

図 2. 分裂期チェックポイント

$\mathrm{M}$ 期は, 染色体や細胞内の小器官が正確に2つの細胞に分離するよう，Mチェッ クポイントによってモニターされている. Mチェックポイントでは, 染色体が赤 道面に整列して, 両方の紡錘極から紡錘糸がすべての姉妹染色体の動原体に付着 するまで決して染色体を分離することがないように調節されている。この機構が 破綻すると，染色体の分配異常が出現する 
胞の出現などが観察される。悪性度の高い腫瘍 では，核の大きさの不均一性や多核細胞の出現 が特徴的な病理像としてみられることが多く, 細胞分裂のステップに異常があることが示唆さ れる。つまりこのような病理像を呈する悪性の 腫瘍細胞ではG1あるいはG 2 チェックポイント の異常に加えて，Mチェックポイントの異常 が生じている可能性が強く考えられる。ひとた び $\mathrm{M}$ 期の制御に異常がおよぶと, 細胞周期が 一回廻るごとに染色体の数や構造に異常が生 じ，細胞は極端な形質变化に陥ると考えられる。

\section{5. 分裂期崩壊と抗癌治療}

アドリアマイシンやシスプラチンをはじめと する多くの抗癌剤はDNA 損傷を誘導するため, 正常細胞では G1 およびG2チェックポイントが 活性化され細胞周期が停止する (図 3 上段)。 停止中に損傷が修復できた細胞は再び細胞周期 に戻るが，修復できなかった細胞はアポトーシ スによって排除される。しかし，多くの癌細胞 ではG1チェックポイントが破綻しているため, DNA 損傷を受けても，G1期で停止せず G2 期
に一時的に貯留する。しかし癌細胞は既に述べ たようにG2チェックポイント機能も低下して いる事が多く，やがて分裂期に進入しその後細 胞死に至る（図 3 中段）。このような細胞死を 分裂期崩壊（mitotic catastrophe）あるいは分 裂死 (mitotic death) と呼んでいる ${ }^{3)}{ }^{4)}$ 。

分裂死は，「DNA損傷を受けた細胞が分裂期 に入ることで細胞死が誘導されること」と定義 され，主に放射線照射治療後における，腫瘍細 胞死の特徵とされてきた。しかしながら，その 分子機構はまだ明確でない。私達は，ヒト癌細 胞株にDNA 損傷を与え, その細胞の分裂期を 動的に観察したところ，G2チェックポイント で停止できず分裂期に入った細胞は，分裂中期 に長時間停止（10～20時間程度）した後に染 色体が分離しないで, 中期から直接死滅するこ とを見出した ${ }^{5)}$ 。また，この分裂中期における 停止は，Mチェックポイントの活性化によっ て誘導されていることが明らかになり，その機 能を抑制すると、染色体分離が急速に進行し, 細胞死を誘導することなく細胞分裂が完遂され ることが分かった（図４）。このように，M チェックポイント機能を抑制することによって

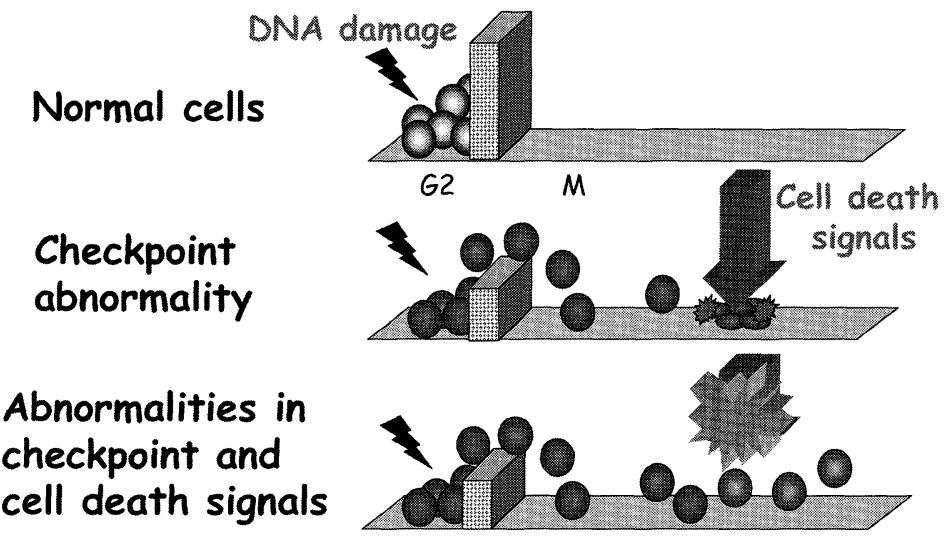

図 3.チェックポイント異常と抗腫瘍治療の関係

正常細胞は G2 チェックポイント機構が保たれているため抗癌剤やX 線などでDNA損傷 を加えるとチェックポイントが活性化され細胞周期が G2 期で停止する (上段)。しかし チェックポイントが障害されている癌細胞ではDNA 損傷後停止することができず，分 裂期に突入することになる。この「チェックポイント乗り越え」によって分裂期崩壊 (mitotic catastrophe) と呼ばれる特徵的な細胞死が誘導される (中段)。これが癌細胞 が正常細胞に比べて特異的に抗癌治療に反応する機構と考えられている。しかし，更に 悪性化した腫瘍ではこの細胞死誘導機構すら破綻しており，「乗り越え」が起こっても 細胞死が誘導できず，治療抵抗性になると考えることができる（下段） 

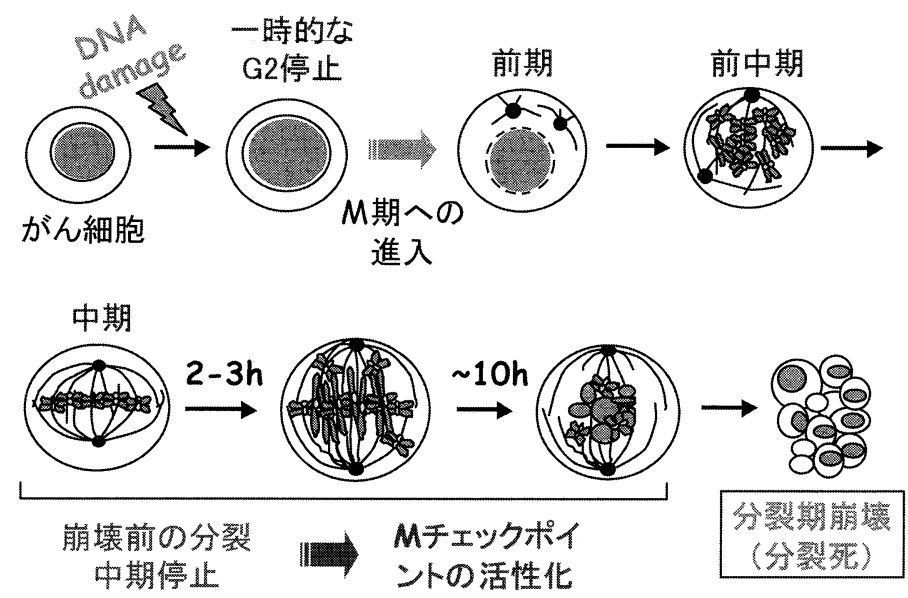

図 4 ．分裂期崩壊の過程

DNA 損傷を受けた癌細胞は一旦 G2 チェックポイントで停止するが，チェック ポイント機能に異常があるため徐々にM期に突入し, 多くの場合分裂期崩壊に より死滅する. 分裂期崩壤の前にみられる分裂中期における停止は $\mathrm{M}$ 期チェッ クポイントの活性化によるものであると考えられ，分裂期崩壊を誘導するため にはM期チェックポイント機能が正常に働く必要性がある

細胞死を回避した細胞では，染色体は不均等に 分離し，微小核などを持つ異常な分裂細胞像が みられた。つまり，DNA損傷後の分裂死には Mチェックポイントの活性化が必要であり, M チェックポイント機能に問題が生じている癌細 胞は，DNA損傷後の分裂死を乗り越え，損傷 を保持したまま新たなDNAの複製を開始し、さ らに悪性化していく可能性が考えられる（図 3 下段)。

多くの癌細胞は G1 期や G2 期チェックポイン 卜異常を持ち, 抗癌剤はその異常を逆に利用し て分裂期崩壞を誘導し，癌細胞を特異的に殺す 方略である。しかし，その分裂期崩壊の誘導に は Mチェックポイント機能が正常であること が前提となる。したがってチェックポイントの 破綻が進んだ癌細胞では，抗癌治療による DNA 損傷をすり抜けて，より悪性化して治療 に抵抗性を示す細胞に変化する可能性がある。 更に私達は，DNA損傷を誘導する薬剤のみな らず，微小管脱重合阻害剂である夕キサン系薬 凨に対する感受性も，Mチェックポイントの 機能障害によって低下することを見出してお $\eta^{6)}$, 各癌細胞に扔けるそのチェックポイント
機能の評価が治療法の選択において重要なファ クターとなる。

\section{文献}

1) Siliciano JD, Canman CE, Taya Y, et al : DNA damage induces phosphorylation of the amino terminus of p53. Genes Dev, 11:3471-3481, 1997

2) Bunz F, Dutriaux A, Lengauer $C$, et al : Requirement for p53 and p21 to sustain G2 arrest after DNA damage. Science, $282:$ 1497-1501, 1998

3) Fingert HJ, Chang JD, Pardee AB : Cytotoxic, cell cycle, and chromosomal effects of methylxanthines in human tumor cells treated with alkylating agents. Cancer Res, 46 :2463-2467, 1986

4) Roninson IB, Broude EV, Chang BD : If not apoptosis, then what? Treatment-induced senescence and mitotic catastrophe in tumor cells. Drug Resist Updat, 4 : 303-313, 2001

5) Nitta M, Kobayashi O, Honda S, et al: Spindle checkpoint function is required for mitotic catastrophe induced by DNA-damaging agents. Oncogene, 3 : 6548-6558, 2004

6) Sudo T, Nitta M, Saya H, et al : Dependence of paclitaxel sensitivity on a functional spindle assembly checkpoint. Cancer Res, $64: 2502-2508$, 2004 